[Radiocarbon, Vol. 11, No. 1, 1969, P. 228-235]

\title{
UNIVERSITY OF WISCONSIN RADIOCARBON DATES VI
}

\author{
MARGARET M. BENDER, REID A. BRYSON, and \\ DAVID A. BAERREIS
}

Department of Meteorology, University of Wisconsin, Madison

The radiocarbon dates obtained since December 1967 are included in this report. The procedures followed have been described previously (Radiocarbon, 1966, v. 8, p. 522-533).

The reported dates have been calculated using 5568 as the half-life of $\mathrm{C}^{14}, 1950$ as the reference year. Samples are counted at least once in each of two $500 \mathrm{ml}$ counters at $3 \mathrm{~atm}$ pressure for a minimum of 15,000 counts. The standard deviation quoted includes only the $1_{\sigma}$ of the counting statistics of background, sample, and standard counts.

ACKNOWLEDGMENTS

This research is supported by the National Science Foundation, Atmospheric Sciences Division, Grant GP-5572X, and Social Sciences Division, Grant GS-1141.

\section{SAMPLE DESCRIPTIONS}

\section{ARCHAEOLOGIC SAMPLES}

\section{A. Wisconsin}

\section{WIS-288. Bornick site, Wisconsin (47MQ65)}

$660 \pm 50$

Test excavations at Bornick site, Marquette County, Wisconsin $\left(43^{\circ}\right.$ $48^{\prime} \mathrm{N}$ Lat, $89^{\circ} 15^{\prime} \mathrm{W}$ Long) were carried out in 1967 by Guy Gibbon, Univ. of Wisconsin-Madison; subm. by D. A. Baerreis. Charcoal from Feature 1, Test Square 21, 1.5 to $2.0 \mathrm{ft}$ below surface. Site is component of Grand River phase, closely related to Walker-Hooper (see below).

WIS-290. Walker-Hooper site, Wisconsin (47GL65)

$\mathbf{7 4 0} \pm \mathbf{5 0}$

Charcoal samples obtained from 1967 excavations by Guy Gibbon at Walker-Hooper site in Green Lake County, Wisconsin $\left(43^{\circ} 42^{\prime} \mathrm{N}\right.$ Lat, $89^{\circ} 09^{\prime}$ W Long), essentially the type site for Grand River phase of Wisconsin Oneota; subm. by D. A. Baerreis. Sample from 0.8 to 1.3 $\mathrm{ft}$ below surface in Level 1, Feature 57, a trash pit. Date agrees well with earlier results (Radiocarbon, 1968, v. 10, p. 475: WIS-268, 270 and 277) of A.D. 1240, 1230, and 1200 respectively.

\section{WIS-315. Dietz site, Wisconsin (47DA12)}

$760 \pm 60$

Charcoal from Dietz site, Dane County, Wisconsin $\left(43^{\circ} 04^{\prime} \mathrm{N}\right.$ Lat, $89^{\circ} 23^{\prime} \mathrm{W}$ Long) of Woodland cultural affiliation. Coll. 1958 and subm. by D. A. Baerreis. Sample from storage or refuse pit, Feature 18. Date 
is in close agreement with earlier ones from same site (Radiocarbon, 1967, v. 9, p. 537: WIS-193) of A.D. 1170 and (Radiocarbon, 1968, v. 10, p. 475: WIS-273) of A.D. 1120.

\section{B. Iowa}

WIS-284. Bastian site, Iowa (13CK28)

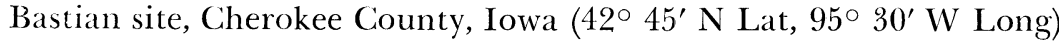
is on high terrace between mouth of Mill Creek and W bank of Little Sioux R. Site has yielded number of large engraved catlinite plaques in addition to other Oneota cultural remains. Pottery appears similar to Correctionville-Dixon variety and to some of Orr focus remains. Charcoal coll. 1966 and subm. by Dale Henning, Univ. of Missouri.

\section{WIS-285. A. C. Banks site, Iowa (13PM40)}

$3860 \pm 65$

Charcoal from A. C Banks site Plymouth County, Iowa $\left(49 \circ 42^{\prime}\right.$ $\mathrm{N}$ Lat, $96^{\circ} 37^{\prime} \mathrm{W}$ Long). Coll. 1967 by R. Banks and D. A. Baerreis; subm. by D. A. Baerreis. Soil samples were coll. at 2 in. intervals in vertical column for recovery of molluscs. This column also produced charcoal, seeds, and flint chips from an occupation zone. Sample dated from $78 \mathrm{in}$. depth, below primary occupation zone at 50 to $62 \mathrm{in.} \mathrm{depth.}$

\section{Rock Run Shelter series, Iowa (13CD10)}

Rock Run Shelter, on small tributary of Cedar R. in Cedar County, Iowa ( $41^{\circ} 42^{\prime} \mathrm{N}$ Lat, $91^{\circ} 11^{\prime} \mathrm{W}$ Long), excavated 1967 by Robert Alex, State Univ. of Iowa, contained sequence of Woodland culture remains in deposit 4.5 to $5.5 \mathrm{ft}$ thick. Coll. 1968 by Robert Alex; subm. by D. A. Baerreis.

\section{WIS-316. Rock Run Shelter site (13CD10)}

Charcoal, small fragments of charred wood, and seed floated from soil sample 8 to 10 in. below original surface level of shelter in Sq. 49$50 \mathrm{X}, 52-53 \mathrm{Y}$.

\section{WIS-320. Rock Run Shelter site (13CD10)}

$$
1630 \pm 60
$$

Charcoal, wood fragments, and nuts, either walnut or hickory nuts, 34 to $36 \mathrm{in}$. below original surface.

\section{WIS-317. Rock Run Shelter site (13CD10)}

$4180 \pm 70$

Charcoal, floated from soil sample, wood, seed, and nut fragments, from Sq. 49-50X, 52-53Y, Excavation Unit 1, 58 to 60 in. below original surface. 


\section{Illinois}

\section{Cahokia site series, Illinois}

Samples from 1967 excavations at Cahokia site, St. Clair County, Illinois (38 $39^{\prime} \mathrm{N}$ Lat, $90^{\circ} 04^{\prime} \mathrm{W}$ Long) under direction of Melvin Fowler, Univ. of Wisconsin-Milwaukee. Logs were found at bottom of deep pit, Feature 1, under Mound 72 apparently to crib or support upright post which had been in pit.

\section{WIS-293. Cahokia site, Illinois}

$\mathbf{9 7 0} \pm \mathbf{5 0}$

$\log B$.

\section{WIS-298. Cahokia site, Illinois}

Log A. Wood could not be id. because of fungal destruction of cells (B. F. Kukachka, U. S. Forest Products Lab, Madison, Wisconsin).

\section{Oklahoma}

\section{Cooper site series, Oklahoma (DL-33 and DL-49)}

Charcoal obtained from excavations at Cooper site, Delaware County, Oklahoma $\left(36^{\circ} 35^{\prime} \mathrm{N}\right.$ Lat, $94^{\circ} 50^{\prime} \mathrm{W}$ Long) of Hopewellian cultural affiliation. Stylistic comparisons of ceramics with Illinois sequences suggest 1 occupation area (DL-33) should antedate the 2nd (DL-49), 500 yds distant from 1st (Baerreis, 1954). Coll. 1939 and subm. by D. A. Baerreis.

\section{WIS-307. Cooper site (DL-33)}

$$
\mathbf{9 8 0} \pm \mathbf{5 5}
$$

Specimen 1146 from Sq. NE 1:17, Level 3, 8 to 12 in. below surface.

\section{WIS-309. Cooper site (DL-49)}

$$
680 \pm 55
$$

Specimen 323 from Sq. 4:8, Level 3, 8 to 12 in. below surface.

\section{WIS-313. Cooper site (DL-49)}

$$
1840 \pm 60
$$

Specimen 1998 from Sq. NE 1:9, Level 3, 8 to 12 in. below surface.

\section{Marrs site series, Oklahoma (BR-18)}

Charred corn cobs from Marrs site, Bryan County, Oklahoma $\left(33^{\circ}\right.$ $55^{\prime} \mathrm{N}$ Lat, $96^{\circ} 35^{\prime} \mathrm{W}$ Long) obtained from excavations in 1941 by $\mathrm{D}$. A. Baerreis; subm. by D. A. Baerreis. Site is type site for Bryan focus (Bell and Baerreis, 1951).

\section{WIS-185. Marrs site, Oklahoma (BR-18)}

$$
400 \pm 50
$$

Burned corn cobs from Cache Pit 55, Grid I-2, Sq. 5:11. Date includes correction of $200 \mathrm{yr}$ based on $\mathrm{C}^{13} / \mathrm{C}^{12}$ enrichment of $1.23 \%$ in corn relative to wood (Bender, 1968). 
WIS-190. Marrs site, Oklahoma (BR-18)

Charred corn cobs from Cache Pit 49, Grid I-2, Sq. 8:8. Date includes correction of $200 \mathrm{yr}$ for carbon isotopic enrichment in corn.

WIS-189. Marrs site, Oklahoma (BR-18)

$630 \pm 60$

Charred corn cobs from Cache Pit 48, Grid I-2, Sq. 20:7, 9 in. below surface. Date includes correction of $200 \mathrm{yr}$ for carbon isotopic enrichment in corn.

\section{GEOLOGIC SAMPLES}

Collection and dating of fossil organic material for the study of Canadian paleo-environments (Wisconsin I-V, Radiocarbon, 1965-1968, v. 7-10) continues with the object of further delineating by palynology and stratigraphy extent and nature of vegetational and climatic changes already established in central and N Canada (Bryson, Larsen, and Irving, 1965; Nichols 1967a, b, c, 1968a, b).

Samples from the base of peat bogs were coll. from S Canada for a study of deglaciation (Bryson and Wendland, 1968) and chronology of peat growth (Nichols, 1968b). Complete peat monoliths dug from pits on exposed banks were coll. for pollen analysis from Peace River (Alberta), Porcupine Mt. (Manitoba), and Colville Lake (Mackenzie). Samples were cleaned in laboratory and cut into $2 \mathrm{~cm}$ slices for $\mathrm{C}^{14}$ assay. Core samples were recovered by a strengthened stainless steel modified-Hiller peat corer with removable aluminum lining $(3.5 \mathrm{~cm}$ diam.) for laboratory extraction of sample. Borer was used in peat less than $200 \mathrm{~cm}$ deep to reduce risk of chamber distortion and down-carriage of upper peat. Samples were taken from a single boring at each site and spanned only $5 \mathrm{~cm}$ vertical distance. To lessen contamination, outer skin of Hiller-type sample was removed in laboratory while inner core remained frozen.

\section{A. Central Canada}

\section{Peace River, Alberta}

Peat bog near town of Peace River, Alberta $\left(56^{\circ} 17^{\prime} \mathrm{N}\right.$ Lat, $117^{\circ}$ $20^{\prime}$ W Long) underlain conformably by sediments of Glacial Lake Peace (Taylor, 1960). Continuous peat monolith $(180 \mathrm{~cm})$ cut from side of pit excavated 1967 by R. A. Bryson, H. Nichols and R. L. Steventon; subm. by $\mathrm{H}$. Nichols. Samples date events in pollen diagram by $\mathrm{H}$. Nichols; basal date has already been reported, WIS-274, 4930 в.c. (Radiocarbon, 1968, v. 10, p. 478).

WIS-300. Peace River, Alberta

Unhumified Sphagnum peat with gymnosperm wood 24 to $26 \mathrm{~cm}$ below modern surface. 
WIS-304. Peace River, Alberta

Wood peat 84 to $86 \mathrm{~cm}$ below surface.

\section{WIS-302. Peace River, Alberta}

Wood peat 110 to $112 \mathrm{~cm}$ below surface.

\section{WIS-311. Peace River, Alberta}

Muddy rootlet peat 130 to $132 \mathrm{~cm}$ below modern surface.

\section{Porcupine Mountain, Manitoba}

Peat bog in kettle on Porcupine Mt $\left(52^{\circ} 31^{\prime} \mathrm{N}\right.$ Lat, $101^{\circ} 15^{\prime} \mathrm{W}$ Long), elev. ca. $2100 \mathrm{ft}$. Monolith cut from side of pit dug 1967 by R. A. Bryson and H. Nichols; subm. by H. Nichols. Samples date events in pollen diagram by $\mathrm{H}$. Nichols; basal date previously reported, WIS271, 4820 B.c. (Radiocarbon, 1968, v. 10, p. 477).

WIS-301. Porcupine Mountain, Manitoba $<\mathbf{2 5 0}$

Unhumified Sphagnum peat 26 to $28 \mathrm{~cm}$ below modern surface.

W IS-287. Porcupine Mountain, Manitoba A.D. 780

Sphagnum peat 50 to $52 \mathrm{~cm}$ below modern surface.

WIS-289. Porcupine Mountain, Manitoba

$$
2000 \pm 55
$$

Sphagnum peat 78 to $80 \mathrm{~cm}$ below modern peat surface.

\section{WIS-303. Porcupine Mountain, Manitoba}

$$
2270 \pm 60
$$

Moderately humified Sphagnum peat, rootlet peat and wood; 100 to $102 \mathrm{~cm}$ below surface.

WIS-306. Porcupine Mountain, Manitoba

$$
2450 \pm 60
$$

Moderately humified Sphagnum peat 116 to $118 \mathrm{~cm}$ below surface.

\section{W IS-286. Porcupine Mountain, Manitoba}

$4180 \pm 75$

Rootlet detritus peat 144 to $146 \mathrm{~cm}$ below modern peat surface.

WIS-308. Porcupine Mountain, Manitoba

$$
5140 \pm 75
$$

Detritus mud 170 to $175 \mathrm{~cm}$ below modern surface.

\section{WIS-281. Mackenzie Highway, Alberta}


1967 from pit excavated near Mackenzie Hwy, Alberta (59 $12^{\prime}$ N Lat, $117^{\circ} 30^{\prime} \mathrm{W}$ Long) by R. A. Bryson, H. Nichols, and R. L. Steventon; subm. by H. Nichols. Sample dated, 50 to $52 \mathrm{~cm}$ below surface, dates initiation of peat growth.

\section{WIS-283. Keg River, Alberta}

R. Alanket of muskeg peat bog covering clay unconformably at Keg

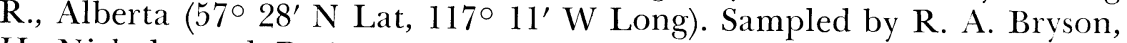
H. Nichols, and R. L. Steventon in 1967 with Hiller-type borer (see above); subm. by H. Nichols. Sample dated was wood peat (overlain by Sphagnum peat) at 115 to $120 \mathrm{~cm}$ below modern surface, overlying blue silty clay at $123 \mathrm{~cm}$; dates initiation of peat growth.

\section{WIS-282. North Star, Alberta}

$$
1870 \pm 60
$$

A.D. 80

Blanket of muskeg peat, primarily Sphagnum spp. at North Star, Alberta $\left(56^{\circ} 42^{\prime} \mathrm{N}\right.$ Lat, $117^{\circ} 38^{\prime} \mathrm{W}$ Long) unconformably overlying minerogenic base of very variable height and character (sand, silt or clay) with wood or charcoal occasionally at base of peat in some borings. Sample coll. 1967 by R. A. Bryson, H. Nichols, and R. L. Steventon with Hiller-type borer; subm. by H. Nichols. Sample dated was crumbly drift peat, 140 to $145 \mathrm{~cm}$ below modern surface, immediately over clay. Dates initiation of peat growth but is minimum date in light of irregular sub-peat surface.

\section{WIS-280. Mann Lake, Alberta}

$4350 \pm 70$

Peat bog in

Alberta Ary $\left(54^{\circ} 10^{\prime} \mathrm{N}\right.$ Lat, $111^{\circ} 28^{\prime} \mathrm{W}$ Long). Sampled in 1967 by R. A. Bryson, H. Nichols, and R. L. Steventon with Hiller-type borer; subm. by H. Nichols. Sample was sandy silty necron mud 195 to $200 \mathrm{~cm}$ below modern surface overlying silty clay conformably at $200 \mathrm{~cm}$. Dates organic accumulation in small lake after mineral inwash from surrounding slopes.

\section{B. Northwest Territories, Canada}

\section{Colville Lake, N.W.T.}

Continuous monolith $(215 \mathrm{~cm})$ coll. 1967 by J. A. Larsen from surface to marl base of exposed peat bank at shore of Colville Lake, Mackenzie, N.W.T. (67०06 $6^{\prime} \mathrm{N}$ Lat, $125^{\circ} 47^{\prime} \mathrm{W}$ Long). Subm. by H. Nichols. Samples date events in pollen diagram by H. Nichols.

WIS-297. Colville Lake, N.W.T.

$1810 \pm 60$

Humified peat 34 to $36 \mathrm{~cm}$ below surface. 
WIS-314. Colville Lake, N.W.T.

$3180 \pm 65$

1230 B.C. surface.

Humified Sphagnum peat with charcoal 44 to $46 \mathrm{~cm}$ below modern

\section{WIS-295. Colville Lake, N.W.T.}

$3980 \pm 65$

2030 B.C. surface.

Moderately humified Sphagnum peat 68 to $70 \mathrm{~cm}$ below modern

WIS-294. Colville Lake, N.W.T.

$4130 \pm 55$

Unhumified Sphagnum peat 90 to $92 \mathrm{~cm}$ below surface.

WIS-296. Colville Lake, N.W.T.

$5730 \pm 75$

3780 B.c.

Unhumified Sphagnum peat 124 to $126 \mathrm{~cm}$ below surface.

WIS-299. Colville Lake, N.W.T.

$6630 \pm 85$

Unhumified Sphagnum peat 174 to $176 \mathrm{~cm}$ below modern surface.

\section{WIS-292. Pelly Lake, N Keewatin, N.W.T.}

$$
2080 \pm 60
$$

130 B.C.

Samples from site ca. $5 \mathrm{mi} \mathrm{N}$ of Pelly Lake, N Keewatin, N.W.T. (66 $05^{\circ} 5^{\prime} \mathrm{N}$ Lat, $101^{\circ} 04^{\prime} \mathrm{W}$ Long). Coll. 1966 and subm. by H. Nichols. Sample dated was coarse sandy detritus mud 26 to $28 \mathrm{~cm}$ below surface.

\section{WIS-312. Repulse Bay, Keewatin, N.W.T.}

A.D. 1660

$290 \pm 55$

At Repulse Bay $\left(66^{\circ} 31^{\prime} \mathrm{N}\right.$ Lat, $86^{\circ} 15^{\prime} \mathrm{W}$ Long) snow bank which survived summer of 1966 in shelter of $10 \mathrm{~m}$ cliff was excavated to reveal underlying fossil plant debris. This material predates climatic deterioration which allowed accumulation of "permanent" bank of snow and ice, and may be comparable with other samples of recent age recovered from beneath ice margins in N Canada (100 B.P., I-408, 200 B.P., I-1674, 330 B.P., I-1204, Andrews, 1967). This falls within period of reduced summer temperatures in Keewatin noted by Nichols (1967c) and of ice advance in N. America and Europe (Porter and Denton, 1967). Sample dated was sandy peat from 2 to $4 \mathrm{~cm}$ below surface of peat. Coll. 1966 by J. A. Larsen; subm. by H. Nichols.

\section{REFERENCES}

Date lists:

Wisconsin I

Wisconsin II

Wisconsin III

Wisconsin IV

Wisconsin $\mathrm{V}$

Bender, Bryson, and Baerreis, 1965

Bender, Bryson, and Baerreis, 1966

Bender, Bryson, and Baerreis, 1967

Bender, Bryson, and Baerreis, 1968

Bender, Bryson, and Baerreis, 1968

Andrews, J. T., 1967, Radiocarbon dates obtained through Geographical Branch field observation: Geog. Bull., v. 9, no. 2, p. 115-162. 
Bacrreis, David A., 1954, Woodland pottery of Northeastern Oklahoma: Prehistoric pottery of the Eastern United States, Museum of Anthropology, Univ. of Michigan,
$18 \mathrm{pp}$.

Bell, Robert E. and Baerreis, David A., 1951, A survey of Oklahoma archaeology: Texas Archaeol. and Paleontol. Soc. Bull., v. 22, p. 7-100.

Bender, Margaret M., 1968, Mass spectrometric studies of carbon 13 variations in corn and other grasses: Radiocarbon, v. 10, no. 2, p. 468-472.

Bender, M. M., Bryson, R. A., and Baerreis, D. A., 1965, University of Wisconsin radiocarbon dates I: Radiocarbon, v. 7, p. $399-407$.

p. 522-533. University of Wisconsin radiocarbon dates II: Radiocarbon, v. 8, p. $530-544$. no. 1, p. $161-168$ no. 2, p. $473-478$

Bryson, R. P. and Wendland, W. M., 1968, Radiocarb Laurentide ice sheet: $25 \mathrm{pp}$.
Laurente ice sheet: Tech. Rept. 35, Univ. of Wisconsin Dept. of Meteorology,

Nichols, H., 1967a, Pollen diagrams from sub-Arctic central Canada: Science, v. 155, p. $166 \check{5}-1668$.

P. $1967 \mathrm{~b}$, Central Canadian palynology and its relevance to northestern Europe in the late Quaternary period: Rev. Palaeobotan. Palynol., v. 2, p. 231-243. Keewatin c, The post-glacial history of vegetation and climate at Ennadai Lake, Keewatin and Lynn Lake, Manitoba (Canada): Eiszeitalter und Gegenwart, v. 18,
p. 176-197.

the arctic 1968a, Pollen analysis, paleotemperatures, and the summer position of the arctic front in the Post-Glacial history of Keewatin, Canada: Am. Met. Soc.
Bull., v. 49, no. 4, p. 387-388. 1968b, Chronology of

climatology, palaeoecology, in peat growth in Canada: Palaeogeography, palaeo-

Porter, S. C. and Denton, G. H., 1967, Chronology of neoglaciation in the North American cordillera: Am. J. Sci., v. 265, p. 177-210.

Taylor, R. S., 1960, Some pleistocene lakes of northern Alberta and adjacent area (revised): J. Alberta Soc. Petrol. Geol., v. 8, no. 6, p. 167-178. 